\title{
PENANGGULANGAN ANAK JALANAN BERBASIS COMMUNITY DEVELOPMENT DI KOTA SERANG
}

\author{
Budi Hasanah dan Liza Diniarizky Putri \\ Jurusan Ilmu Administrasi Negara, Universitas Serang Raya, Indonesia \\ budihasanah@gmail.com
}

\begin{abstract}
Children must receive good education, positive parenting, protection and other rights so that they can growth properly. But actually, it did not happen in Kota Serang. It was caused by the increasing number of street children. There were increasing number of street children in 2016, 31 children so until now the total was 181 children. This research was about the prevention of street children based on community development with conflict theme and intervention model. This research used biddle theory with three indicators: explanatory, organizational and discussional. This research used qualitative with descriptive method. The data from interview and deep discussion as well as observation used interactive model analysis. The results showed that there were some factors behind the number of street children in Kota Serang. Based on the FGD results, an alternative solution was need to reactivation the existing halfway house and form special team to take care the childreen who live there. Thus, the prevention of street childreen based on community development program could be run effectively.
\end{abstract}

Keywords: Prevention, Stree Children, and Community Development

\begin{abstract}
ABSTRAK
Anak-anak harus menerima pendidikan yang baik, pengasuhan yang positif, perlindungan yang membuat anak-anak merasa aman dan pemenuhan hak-hak lainnya yang harus diterima oleh mereka. Namun hal ini bertolak belakang dari yang diharapkan salah satunya yang terjadi di Kota Serang. Jumlah anak jalanan yang semakin meningkat, pertambahannya sebanyak 31 anak pada tahun 2016 dengan total 181 anak. Penelitian ini akan mengupas penaggulangan anak jalanan berbasis community development dengan tema konflik dan model intervensi. Penelitian ini menggunakan teori Biddle dengan mengambil tiga indikator yaitu Exploratory, Organizational, Discussional. Penelitian ini menggunakan pendekatan kualitatif dengan metode dekriptif. Data penelitian ini bersumber pada wawancara dan diskusi mendalam dan pengamatan langsung dengan menggunakan interactive model analysis. Hasil penelitian yang didapat bahwa terdapat faktor yang melatarbelakangi banyaknya jumlah anak jalanan di Kota Serang dan untuk menghasilkan alternatif menanggulangi permalahan tersebut dengan menggunakan metode FGD didapat bahwa perlu diaktifkan kembali rumah singgah yang sudah ada dengan membentuk tim khusus penanggulangan anak jalanan yang bertempat di rumah singgah sehingga program penanggulangan anak jalanan berbasis community development bisa difungsikan dengan efektif.
\end{abstract}

Kata Kunci: Penanggulangan, Anak jalanan, Community Development

Diterima 21 Juni 2019; Diterima dengan revisi 4 Oktober 2019; Dipublikasikan 1 Desember 2019 2406-9515 (p) / 2528-441X (e)

(C) 2019 Budi Hasanah, Liza Diniarizky Putri. Dipublikasikan oleh JAP FIS UNY 


\section{PENDAHULUAN}

"Anak-anak adalah masa depan bangsa", itulah istilah yang sering kita dengar. Bukan tanpa maksud, artinya anak-anak memiliki potensi sebagai bagian dari sumber daya manusia yang berpotensi besar sebagai penerus bangsa. Keberadaan anak-anak harus diperhatikan. Sudah jelas di dalam UUD 1945, hak-hak pada anak sangat dilindungi oleh negara sekalipun anak tersebut belum terlahir di dunia. Terdapat 4 (empat) hak dasar anak yaitu hak hidup, hak tumbuh kembang, hak partisipasi, hak perlindungan (Fitri, Riana, \& Fedryansyah, 2015).

Melihat adanya hak dasar anak yang harus dipenuhi tetapi pada realita yang ada justru sebaliknya, tidak sedikit hak-hak anak yang dimaksud diabaikan begitu saja salah satunya di Kota Serang. Banyak anak-anak yang banyak menghabiskan waktunya di jalan yang dapat disebut sebagai anak jalanan. Anak jalanan menurut world health organization (WHO) adalah sebelum usia 18 tahun dan yang belum menikah. Dalam The Age Convention on The Right of The Child (1989) anak adalah mereka yang berumur 18 tahun kebawah. Sedangkan, menurut The Minimum Age Convention nomor 138 tahun 1973, anak adalah seseorang yang berusia 15 tahun kebawah. Sementara, UNICEF mendefenisikan anak sebagai penduduk yang berusia antara 0 sampai 18 tahun. Berdasarkan Penelitian dinegara Zimbabwe, Anak jalanan merupakan anak-anak yang sepenuhnya tinggal dijalanan dan tidak mendapatkan perlindungan dari orang tua atau keluarga (Suzzana, 2018)

\section{Tabel 1. Karakteristik Katerlantaran pada Anak Jalanan Kota Serang}

\begin{tabular}{|c|c|c|c|c|c|c|c|}
\hline \multirow{4}{*}{ No } & \multirow{4}{*}{ Kecamatan } & \multicolumn{6}{|c|}{ Keterlantaran } \\
\hline & & \multicolumn{6}{|c|}{ Anak Jalanan } \\
\hline & & \multicolumn{3}{|c|}{ Tahun 2015} & \multicolumn{3}{|c|}{ Tahun 2016} \\
\hline & & $\mathrm{L}$ & $\mathrm{P}$ & Jumlah & $\mathrm{L}$ & $\mathrm{P}$ & Jumlah \\
\hline 1 & 2 & 3 & 4 & 5 & 6 & 7 & 8 \\
\hline 1 & Curug & 8 & 0 & 8 & 4 & 0 & 4 \\
\hline 2 & Walantaka & 8 & 3 & 11 & 1 & 0 & 1 \\
\hline 3 & Cipocok Jaya & 48 & 2 & 50 & 14 & 1 & 14 \\
\hline 4 & Serang & 54 & 7 & 61 & 117 & 13 & 130 \\
\hline 5 & Taktakan & 4 & 1 & 5 & 2 & 0 & 2 \\
\hline 6 & Kasemen & 10 & 5 & 15 & 13 & 16 & 29 \\
\hline & Jumlah & 132 & 18 & 150 & 151 & 30 & 181 \\
\hline
\end{tabular}

(Sumber : Dinas Sosial kota Serang, 2015-

Berdasar table 1 terlihat bahwa terdapat peningkatan jumlah anak jalanan dari tahun 2015 sampai tahun 2016 yaitu sebanyak 31 anak dimana secara keseluruhan pada tahun 2015 sebanyak 150 anak dan 181 anak pada tahun 2016 dan terlihat Kecamatan Serang menduduki peringkat pertama dengan jumlah anak jalanan terbanyak di Kota Serang yaitu sebanyak 61 anak pada tahun 2015 dan pada tahun 2016 sebanyak 130 anak.

Penanganan anak jalanan dengan keadaan yang saat ini sangat memprihatinkan maka harus sesegera 
mungkin diselesaikan segala permasalahan yang ada karena jika diabaikan maka akan mengancam masa depan bangsa. Pada penelitian terdahulu telah ditemukan beberapa model-model kebijakan penanggulangan anak jalanan seperti yang dilakukan di Semarang dimana dalam pelaksanaannya digunakan empat model pendekatan yakni pertama, model pendekatan berbasis panti sosial atau institutional based service; kedua, model pendekatan berbasis keluarga atau family based services; ketiga, model pendekatan berbasis masyarakat atau community based services dan (4) model pendekatan berbasis semi panti sosial atau half-way house services ((Ronawaty Anasiru, 2011)

Adapaun penelitian lain yang membahas mengenai penanganan anak jalanan ini seperti yang diungkapkan oleh (Susilowati, 2017) dimana peran orang tua sangat penting dalam penanggulangan anak jalanan. Orang tua seringkali keberatan ketika anaknya dibina untuk memperoleh keterampilan di lembaganya hanya karena waktu yang seharusnya dapat digunakan untuk mencari uang menjadi tidak bisa selain itu, faktor kemiskinan yang menjadi faktor utama munculnya anak jalanan maka pemerintah, LSM dan masyarakat harus bersinergi untuk memberdayakan keluarga anak jalanan, dengan meningkatnya ekonomi keluarga maka anak dapat fokus untuk menempuh pendidikan. Selain itu, menurut (Putri et al., 2015) dalam penanganan anak jalanan yaitu pemerintah membentuk program Kesejahteraan Sosial Anak (PKSA). Jika melihat berbagai program yang telah ada dan telah diupayakan oleh pemerintah Kota Serang dengan basis community develoment (pengembangan masyarakat atau komunitas) yaitu Program Post Sahabat Anak dan Rumah Singgah.

Menurut Budimanta, community development adalah kegiatan pembangunan masyarakat yang dilakukan secara sistematis, terencana dan dan diarahkan untuk memperbesar akses masyarakat guna mencapai kondisi sosial, ekonomi dan kualitas hidup yang lebih baik apabila dibandingkan dengan kegiatan pembangunan sebelumnya (Ismail et al., 2017; Triyono, 2014; Soetomo, 2008; Widayanti, 2012). Administrator publik disarankan untuk terlibat dalam pertanyaan kebijakan publik mengenai penanggulangan anak jalanan "apa yang harus dilakukan", bukan bagaimana melakukannya." Mereka memobilisasi aktor-aktor kunci dan membantu membuat kebijakan 
teraktualiasi (Frank Fischer et al, 2014:204). Pada penelitian ini terkait penanggulangan anak jalanan di Kota Serang dengan menggunakan model community development dimana dalam pemenuhan hak-hak anak yang dimaksud dapat dilakukan dengan cara pengembangan komunitas di Kota Serang.

Hak-hak anak merupakan bagian integral dari HAM (Hak Asasi Manusia) berkaitan dengan peranan negara maka tiap negara mengembankan kewajiban yaitu melindungi (to protect), memenuhi (to fulfill) dan menghormati (to respect) hak-hak anak. Lebih jelasnya bisa dilihat di bawah ini terkait komponen sistem dalam memberikan kesejahteraan kepada anak-anak.

Pada konsep community development ini, peneliti menggunakan tema dan model dalam menanggulangi anak jalanan di Kota Serang. Secara garis

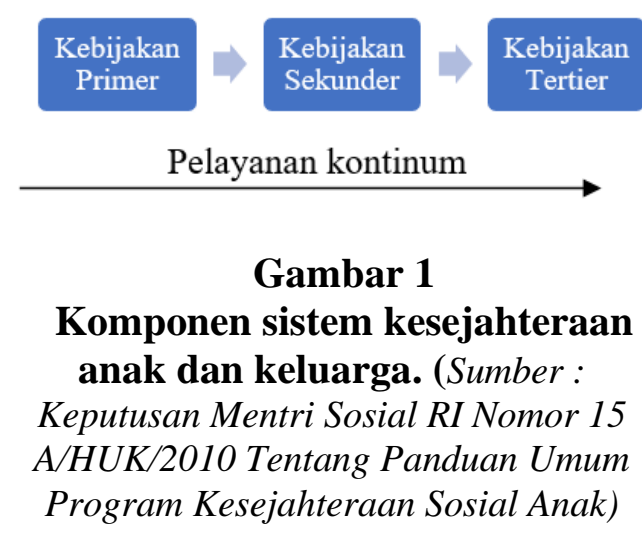

besar tedapat beberapa tema tetapi yang sesuai dengan penelitian ini yaitu dengan tema "konflik" dan modelnya yaitu model “intervensi." Tema konflik didasari dan didorong oleh kesadaran bahwa dalam masyarakat terutama melalui struktur sosialnya terjadi berbagai bentuk ketidakadilan dan ketimpampangan seperti yang dialami oleh anak-anak jalanan di Kota Serang sehingga mengakibatkan taraf hidup sebagian dari mereka menjadi rendah. Rendahnya taraf hidup ini disebabkan karena dalam upaya pemenuhan kebutuhan dan peningkatan taraf hidup mendapat berbagai hambatan struktural.

Untuk mengatasi hal tersebut dibutuhkan serangkaian tindakan dan gerakan guna mewujudkan perubahan dan reformasi dalam masyarakat. Dengan demikian, community development menurut pendekatan ini merupakan suatu gerakan untuk mengadakan reformasi bahkan tranformasi terhadap kondisi yang dianggap kurang menguntungkan. Pada tema ini memiliki karakteristik memerhatikan baik proses maupun hasil material, cepat dalam menumbuhkan perubahan karena tujuannya memang melakukan reformasi atau bahkan transformasi. Selanjutnya, intervensi dalam community development lebih 
berfungsi sebagai stimulan untuk mendorong tumbuhnya prakarsa dan teraktualisasinya potensi dari dalam. Pada model ini, intervensi dapat dilakukan oleh badan-badan atau instansi pemerintah maupun nonpemerintah.

Dengan demikian, dlihat dari kepentingan masyarakat lokal maupun masyarakat nasional, intervensi melalui community development setidaknya memberikan manfaat berupa: (1) mempercepat proses perubahan dan pembaruan pada tingkat komunitas lokal, (2) memberikan iklim yang kondusif bagi masyarakat pada tingkat komunitas untuk menciptakan, mengembamgkan dan memanfaatkan peluang bagi peningkatan taraf hidupnya. Menurut Biddle dalam Soetomo (2008:153), agar intervensi dari luar dapat mendorong tumbuhnya kompetensi masyarakat dan memuculkan prakarsa lokal, maka butuh adanya tahapan dalam pelaksanaannya, yaitu tahap Exploratory, Organizational, Discussional, Action, New project dan Continuation. Berdasarkan program penanggulangan anak jalanan berbasis komunitas tersebut akan dilihat bagaimana program itu berjalan sampai saat ini serta akan mengeksplor seputar permalahan mengenai anak jalanan dan menentukan media yang dapat digunakan sebagai sarana pertemuan dan diskusi dengan masyarakat untuk mencari alternatif penyelesaian permalahan anak jalanan.

\section{METODE}

Kebijakan primer meliputi pendidikan masyarakat, penyebarluasan informasi dan peningkatan sesitisasi/kesadaran pihak-pihak terkait tentang kesejahteraan dan perlindungan anak. Sedangkan, kebijakan sekunder berupa penguatan/dukungan tanggung jawab keluarga dalam peningkatan kesejahteraan sosial anak serta intervensi dini dalam penjegahan masalah anak. Adapun kebijakan tertier adalah pemberian pelayanan kesejahteraan dan perlindungan anak berupa dukungan intensif terhadap keluarga dan pengasuhan anak di luar keluarganya serta pelayanan perlindungan sosial secara langsung terhadap anak yang menjadi korban penelantaran, kekerasan, eksploitasi, dan diskriminasi.

$$
\text { pada konsep community }
$$
development ini, peneliti menggunakan tema dan model dalam menanggulangi anak jalanan di Kota Serang. Secara garis besar tedapat beberapa tema tetapi yang sesuai dengan penelitian ini yaitu dengan tema "konflik" dan modelnya yaitu model “intervensi." Tema konflik 
didasari dan didorong oleh kesadaran bahwa dalam masyarakat terutama melalui struktur sosialnya terjadi berbagai bentuk ketidakadilan dan ketimpampangan seperti yang dialami oleh anak-anak jalanan di Kota Serang sehingga mengakibatkan taraf hidup sebagian dari mereka menjadi rendah. Rendahnya taraf hidup ini disebabkan karena dalam upaya pemenuhan kebutuhan dan peningkatan taraf hidup mendapat berbagai hambatan struktural. Untuk mengatasi hal tersebut dibutuhkan serangkaian tindakan dan gerakan guna mewujudkan perubahan dan reformasi dalam masyarakat. Dengan demikian, community development menurut pendekatan ini merupakan suatu gerakan untuk mengadakan reformasi bahkan tranformasi terhadap kondisi yang dianggap kurang menguntungkan. Pada tema ini memiliki karakteristik memerhatikan baik proses maupun hasil material, cepat dalam menumbuhkan perubahan karena tujuannya memang melakukan reformasi atau bahkan transformasi. Selanjutnya, intervensi dalam community development lebih berfungsi sebagai stimulan untuk mendorong tumbuhnya prakarsa dan teraktualisasinya potensi dari dalam. Pada model ini, intervensi dapat dilakukan oleh badan-badan atau instansi pemerintah maupun nonpemerintah.

Dengan demikian, dlihat dari kepentingan masyarakat lokal maupun masyarakat nasional, intervensi melalui community development setidaknya memberikan manfaat berupa: (1) mempercepat proses perubahan dan pembaruan pada tingkat komunitas lokal, (2) memberikan iklim yang kondusif bagi masyarakat pada tingkat komunitas untuk menciptakan, mengembamgkan dan memanfaatkan peluang bagi peningkatan taraf hidupnya. Menurut Biddle dalam Soetomo (2008:153), agar intervensi dari luar dapat mendorong tumbuhnya kompetensi masyarakat dan memuculkan prakarsa lokal, maka butuh adanya tahapan dalam pelaksanaannya, yaitu tahap Exploratory, Organizational, Discussional, Action, New project dan Continuation. Pada penelitian ini akan dilakukan mulai dari pada tahap Exploratory sampai pada tahap Discussional karena pada tahap ini yang sesuai dengan penelitian ini. Lebih jelasnya bisa dilihat pada uraian di bawah ini:

1) Exploratory: pemahaman terhadap kondisi, situasi dan potensi masyarakatnya. Dalam tahap ini juga diusahakan memperoleh 
informasi yang dapat digunakan untuk berkomunikasi dengan masyarakat pada tahap selanjutnya. Bagi petugas lapangan, kesempatan pada tahap ini juga dapat dipergunakan untuk memperkenalkan diri dan memahami respons masyarakat atas kehadirannya.

2) Organizational: penentuan media yang dapat digunakan sebagai sarana pertemuan dan diskusi antara petugas dengan masyarakat maupun antarsesama warga masyarakat serta pembuatan langkah-langkah untuk menangani masalah pada tingkat komunitas.

3) Discussional: tahap ini berisi kegiatan diskusi antar warga masyarakat tentang inventarisasi masalah serta kemungkinan pemecahannya, memilih alternatif yang pantas memperoleh prioritas dalam penanganannya, membuat keputusan tentang kegiatan bersama yang akan dilaksanakan dan membuat rencana pelaksanaannya.

4) Action: tahap ini berisi pelaksanaan kegiatan yang sudah diputuskan bersama serta melaporkan dan mengevaluasi hasilnya.
5) New project: tahap ini mengulang kegiatan diskusi untuk menentukan masalah apa yang sebaiknya digarap pada prioritas berikutnya kemudian membuat rencana dan melaksanakannya dengan memerhatikan pengalaman pelaksanaan sebelumnya. Dengan cara yang sama, dilakukan kegiatankegiatan berikutnya sesuai urutan prioritas berdasarkan kesepakatan warga masyarakat.

6) Continuation: tahap ini mekanisme pelaksanaan pembangunan berdasar prakarsa masyarakat dianggap sudah melembaga. Petugas lapangan dapat meninggalkan masyarakat yang bersangkutan. Walaupun inteevensi dari luar sudah dihentikan, kesinambungan proses pembangunan diharapkan tetap berjalan.

Berdasarkan program penanggulangan anak jalanan berbasis komunitas tersebut akan dilihat bagaimana program itu berjalan sampai

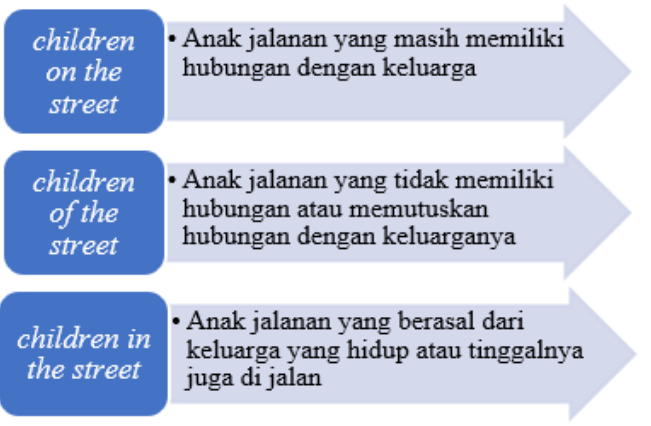

Gambar 2. Kategori Anak Jalanan 
saat ini serta akan mengeksplor seputar permalahan mengenai anak jalanan dan menentukan media yang dapat digunakan sebagai sarana pertemuan dan diskusi dengan masyarakat untuk mencari alternatif penyelesaian permalahan anak jalanan.

\section{HASIL DAN PEMBAHASAN}

\section{Exploratory}

karakteristik anak jalanan yang tersebar di Kota Serang berasal dari latar belakang yang beragam, mulai dari latar belakang keluarga sampai pada latar belakang perekonomian dan hukum sehingga anak-anak banyak yang melakukan aktifitasnya di jalan yang pada akhirnya kita sebut sebagai anak jalanan. Jika kita lihat, anak jalanan yang memang asli domisili dari Kota Serang masih memiliki keluarga tetapi ada pula anak jalanan yang bukan berdomisili asli dari Kota Serang. Hal ini ditemukan bahwa banyak anak jalanan yang berasal dari daerah lain seperti berasal dari daerah Bogor, Jakarta, Merak, Lampung, Palembang, Surabaya. Dari sini kita dapat mengelompokan anak jalanan menjadi 3 (tiga) kelompok yaitu kelompok children on the street, children of the street dan children in the street (Media Cetak Radar Banten (17/5/2018), berikut penjelasannya.
Berdasar kategori anak jalanan di atas, anak jalanan yang berada di kota Serang dapat masuk kedalam semua kategori. Hal ini dikarenakan kondisi anak jalanan di Kota Serang sudah kompleks dimana tidak hanya berasal dari daerah Kota Serang tetapi banyak juga yang berasal luar daerah Kota Serang.

Anak yang asli Kota Serang masuk pada kelompok atau kategori yang banyak melakukan aktifitasnya di jalan namun setelah aktifitasnya selesai, mereka pulang ke rumah masing-masing. Namun, anak-anak yang bukan asli Kota Serang melakukan aktifitas di jalan bersama orang tuanya, ada juga yang memang sampai pada 24 jam di jalan dan mereka tidak pulang ke rumah dengan kata lain mereka putus hubungan dengan orang tuanya. Ditemukan kasus dimana anak-anak sekitar usia 14-15 tahun yang berasal dari Palembang dan Surabaya ada yang melakukan operasi di sekitar daerah Bunderan Ciceri, mereka telah lari dari rumah karena sering dimarahi oleh orang tuanya dan dipaksa untuk membantu orang tua bekerja mencari uang. Adapun kasus lain yaitu 3 (tiga) anak perempuan yang merupakan saudara (kakak beradik) yang berasal dari daerah Keragilan. Mereka mencari uang di sekitar daerah 
Ciceri dengan cara mengamen atau bahkan meminta-minta. Waktu subuh mereka baru pulang ke rumah dan uangnya disetorkan ke orang tuanya. Ada pula anak yang pulangnya ke daerah Merak sampai pada waktu subuh dimana kebanyakan dari mereka karena faktor ekonomi.

Berbicara mengenai nilai anak, terdapat 2 (dua) yaitu nilai histori dan ekonomi. Jika nilai histori yang merupakan bagaimana memaksakan anaknya supaya seperti orang tuanya sedangkan nilai ekonomi yaitu bagaimana orang tua atau orang dewasa memekerjakan anaknya di jalanan. Kehidupan di jalan sangat rentan dengan adanya tindak kekerasan dan hal ini dialami oleh anak-anak yang menghabiskan hidupnya di jalan. Antara lain, kekerasan fisik sampai pada keprihatinan kita mengenai anak jalanan yang bebas bermain di warnet (warung intenet) mulai dari bermain games sampai pada bebasnya mengakses yang berbau

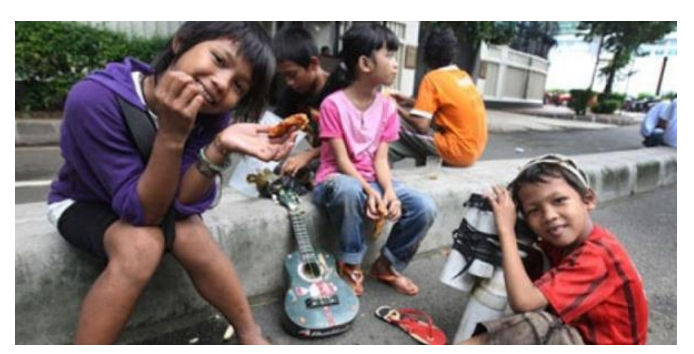

Gambar 3. Anak Jalanan di Kota Serang. (Sumber : RMOL Banten, 2018) pornografi. Pada aspek kesehatan juga rentan terhadap banyaknya polusi seperti polusi udara. Keprihatinan disini pasti terdapat hak-hak anak lainnya yang terabaikan dimana hal ini seharusnya mereka terima diantaranya yaitu hak memperoleh pendidikan, bersosialiasi dengan teman sebaya dan tetangga bahkan memperoleh kasih sayang yan diterima di rumah atau keluarga (orang tua) tetapi akhirnya mereka berhadapan dengan banyaknya ancaman.

$$
\text { Banyaknya ancaman yang }
$$
diperoleh dari anak jalanan itu sendiri tetapi ancaman ini berdampak pula pada masyarakat yang terganggu dengan keberadaan anak jalanan. Masyarakat dibuat resah terutama masyarakat yang berkendara. Para pengamen yang kebanyakan anak jalanan, anak-anak punk yang hampir setiap lampu merah yang akhirnya ada juga yang melakukan pemaksaan meminta uang atau bahkan meminta rokok. Hal ini sangat mengganggu pengendara sepeda motor dan dikhawatirkan terjadinya kecelakaan. Dari berbagai permsalahan tersebut, ada juga warga pengendara baik kendaraan beroda dua atau empat atau bahkan truk memberikan berupa uang atau bahkan rokok. Walaupun memang dibanding dengan daerah lain, anak jalanan yang 
berada di Kota Serang masih terbilang sopan, berbeda dengan daerah lain seperti di kota-kota besar yaitu Jakarta misalnya dimana kehidupan anak jalanan lebih keras. Tetapi, bukan berarti kita abai terhadap permasalahan ini karena pemenuhan hak-hak anak tidak ada kata terkecuali selain terpenuhinya kebutuhan mereka secara adil sesuai amanat konstitusi dan regulasi yang ada.

\section{Organization}

Pada indikator ini, penentuan media yang dapat digunakan sebagai sarana pertemuan dan diskusi dengan masyarakat dalam hal ini adalah orang tua anak jalanan serta pembuatan langkah awal untuk menangani masalah pada tingkat komunitas (Kota Serang) yaitu dengan menggunakan media FGD (Focus Group Disscusion) yang merupakan proses pengumpulan informasi mengenai penanggulangan anak jalanan melalui diskusi kelompok.

\section{Disscusion}

Permasalahan anak jalanan masih menjadi pekerjaan rumah bagi pemerintah daerah Kota Serang. Hal ini bukan tanpa alasan karena sampai saat ini masih banyak anak-anak yang melakukan berbagai aktivitasnya di jalan dengan waktu yang cukup lama sehingga disebut dengan anak jalanan. Dalam menyelesaikan masalah anak jalanan sudah pasti pemerintah sudah pasti tidak dapat berjalan sendiri dalam memanggulangi permasalahan ini karena butuh adanya kerjasama dari berbagai pihak termasuk masyarakat pada umumnya. Oleh karena itu, dalam peyelesaian ini terdapat model penanggulangan anak jalanan yaitu berbasis pengembangan masyarakat atau komunitas yang sering kita kita sebut dengan community devepoment.

Sampai saat ini, sebenarnya pemerintah sudah mengeluarkan atau mengesahkan program penanggulangan anak jalanan berbasis community development yaitu pada program Pos Sahabat Anak yang merupakan program percontohan dari Provinsi Banten dimana program ini telah di konsep pada tahun 2014. Selanjutnya pada tahun 2017 telah di hibahkan untuk Dinas Sosial Kota Serang. Tetapi program ini sudah tidak berjalan lagi. Hal ini dikarenakan 2 (dua) dari 3 (tiga) post sahabat anak telah melanggar hukum terkait pendirian atau pembangunannya yaitu di atas jalur pedestrian yang tidak sesuai dengan peraturan pemerintah daerah Kota Serang Nomor 10 tahun 2010 tentang Ketertiban, Kebersihan dan Keindahan. Titik pendirian atau pembangunan tersebut 
yaitu di atas trotoar di daerah Kebon Jahe dan Ciceri sedangkan yang lain dibangun di lingkungan Alun-alun Barat.

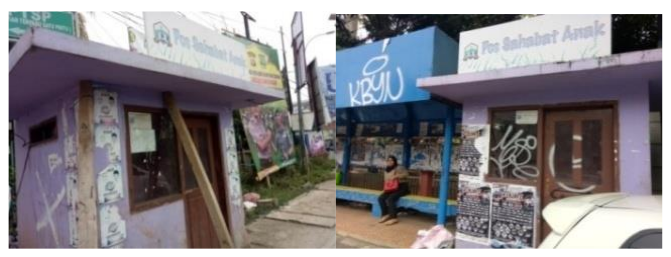

Gambar 5 dan 6: Post Sahabat Anak di atas trotoar daerah kebon Jahe dan Ciceri samping Halte UIN Maulana Yusuf Serang. (Sumber : Peneliti, 2018)

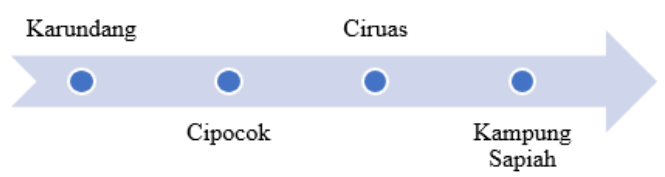

\section{Gambar 7. Perpindahan Rumah}

Singgah (Sumber : Peneliti, 2018)

Walaupun program ini merupakan program perdana penanggulangan anak jalanan tetapi program ini sampai saat ini terlihat kondisi bangunannya tidak layak dan sudah terbengkalai, tidak terurus serta sangat memritinkan dimana seharusnya bangunan ini dirobohkan dan trotoal tersebut dimanfaatkan sesuai dengan fungsinya. Hal ini memperlihatkan bahwa pemerintah dalam hal ini yang memiliki wewenang dalam membuat regulasi terkait penanggulangan anak jalanan belum matang sehingga pada saat implementasi kebijakan tersebut tiadak dapat menyelesaikan permasalahan yang ada.

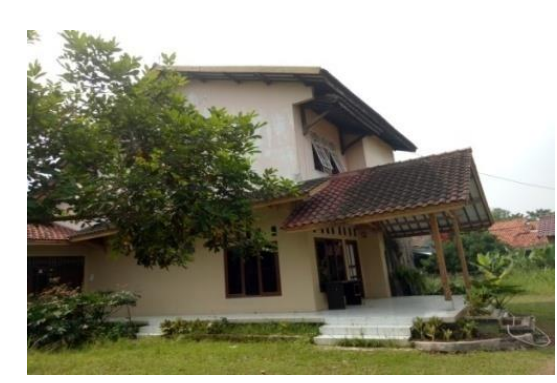

Gambar 8. Rumah Singgah (Sumber : Peneliti, 2018)

Selain program pos sahabat anak, program penanggulangan berbasis community development yaitu Program Rumah singgah yang telah dibuat oleh Dinas Sosial Kota Serang itu sendiri. Program ini dibentuk karena diketahui program post sahabat anak tidak berjalan namun rumah yang dijadikan program sampai saat ini sifatnya masih ngontrak dan letaknya pun kurang strategis. Jadi sampai saat ini program rumah singgah hanya sekedar tempat yang kurang difungsikan dengan baik. Oleh karena itu, kegiatan penanggulangan anak jalanan jadi terhambat dan terlambat. Sampai saat ini rumah singgah sudah 4 (empat) kali pindah lokasi, dapat dilihat pada gambar berikut.

Awal mula dibentuknya program rumah singgah yaitu sejak tahun 20142015 dimana yang mencetuskan yaitu kepala OPD terkait Kepala Dinas Sosial Kota Serang pada saat itu masih menjabat. Fungsi rumah singgah yaitu untuk menampung hasil razia yang 
kemudian dilakukan pendataan dan seharusnya sebagai tempat menginap dan dilakukan pembinaan dan pelatihan. Rumah singgah ini tidak hanya difungsikan untuk anak jalanan tetapi untuk segala hasil razia yang tergolong penyakit masyarakat. namun sampai saat ini, rumah singgah tersebut tidak difungsikan sebagai mestinya. Karena faktor pemerintah yang belum mampu mengelola rumah singgah tersebut termasuk pada minimnya keseriusan pemerintah dalam menyelesaikan permasalahan ini dan minimnya anggaran serta SDM yang memadai. Berikut gambar rumah singgah yang terletak di Kampung Sapiah.

Permalalahan anak jalanan yang tidak kunjung mendapatkan solusi yang tepat yaitu faktor pendekatan yang kurang tepat dalam melakukan penghalauan atau razia yang dilakukan oleh Satuan Pamong Praja Kota Serang beserta petugas dari Dinas Sosial Kota Serang. Pendekatan dalam penanganan anak jalanan seharusnya berbeda dengan penanganan permasalahan sosial lainnya yanag masuk ke dalam penyakit amsyarakat yang dilakukan oleh orang dewasa. Perbedaan karakteristik baik dari segi permalahannya sampai pada usia seharusnya berbeda pula pendekatan yang dilakukan. Selain itu, komunikasi yang dilakukan diantara mereka pun harus tepat yang seharusnya tidak boleh menggunakan kekerasan dengan membawa atribut razia seperti pentungan tetapi adanyanya penanganan secara baik seperti membawakan makanan, bawa apa yang anak jalanan suka. Intinya, bukan untuk menakuti anak-anak tetapi untuk mengetahui secara jelas alasan anak-anak banyak menghabiskan waktunya di jalan dan asal usul dari anak-anak tersebut. Dengan menggunakan pendekatan yang lebih soft membuat anak-anak nyaman yang kemudian mereka dapat bercerita dengan baik dan jujur. Sebenarnya anakanak memiliki cita-cita yang dan mimpi yang baik seperti ingin menjadi guru, TNI dan sebagainya. Oleh karena itu, disini perlu adanya perbaikan SOP jika sampai saat ini pendekatan yang dipakai membuat anak-anak menjadi takut yang mengakibatkan penanganannya tidak sampai ke hulunya. Dinas sosial merupakan gerbang utama yang kemudian dilakukan pemetaan dan di urai permalahannya. Misal ditemukan orang tua dari anak tersebut tidak memiliki pekerjaan karena faktor pendidikan dan tidak adanya skill maka Dinas UMKM yang memberikan pelatihan agar orang tua menjadi produktif yang berdampak 
pada pertahanan perekonomian menjadi kuat sehingga dapat membiayai anaknya sekolah. Selain itu, jika kondisi orang tuanya yang sudah tidak lagi berdaya dan keluarga besarnya pun tidak mampu untuk membiayai kehidupan anak tersebut maka tugas negara dengan mengirim anak tersebut ke panti atau yayasan yang bermitra dengan dengan Dinas Sosial Kota Serang untuk di bina.

Program rumah singgah dimana sekarang bertempat di kampung Sapiah, banyak warga Sapiah yang tidak tahu keberadaan dan fungsi dari rumah tersebut. Fungsi rumah singgah tersebut seharusnya tidak hanya sebagai tempat pendataan tetapi ada kegiatan pembinaan, pemulihan mental dan spiritual yang kemudian dipetakan permasalahannya sehingga perlu adanya peran dinas lain dalam penangannya. Selain itu, butuh adanya kerjasama lintas daerah yang terintegratif jika anak jalanan yang terdata bukan berdomisili Kota Serang. Selain itu, jika orang tua sudah melakukan eksploitasi anak dan melakukan kekerasan maka harus masuk ke jalur hukum dimana hal ini harus berkoordinasi dengan pihak kepolisian. Tetapi, jika masih bisa dilakukan pembinaan, pemberdayaan maka perlu terlebih dahulu jalur ini digunakan. Disini harus adanya tim psikolog untuk berbicara dengan orang tua dan anakanak sehingga mereka tidak memberikan keterangan yang tidak sebenarnya.

Penanggulangan anak jalanan berbasis community development juga telah dilakukan oleh komunitas pada skala yayasan salah satunya adalah Yayasan Bina Wanita Bahagia yang secara administratif sudah legal keberdaannya di mata hukum dan sudah bekerja sama dengan Dinas Sosial Kota Serang namun mereka masih mengalami keterbatasan dalam pemenuhan secara operasional terkait pendanaan. Jika berbicara dalam skup makro, Pemerintah Kota Serang memang dalam APBD untuk menanggulangi masalah anak jalanan belum menjadi skala prioritas yang berdampak pada terhambatnya penyelesaian masalah ini.

Pada penanganan anak jalanan harus memiliki wadah yang jelas agar dpat terarah prosesnya sehingga tujuannya dapat di capai dengan baik. Tetapi dalam hal ini tidak hanya sekedar, perlu adanya keseriusan dan konsistensi serta komitmen bersama yang dapat dilakukan dianatarnya dengan pemenuhan anggaran dan SDM yang cukup baik. Selain itu, permasalahan anak jalanan ini pada intinya tidak hanya 
karena tidak terpenuhinya hak sebagai anak. Namun, semua bermuara dari ketahanan keluarga maka dari itu perlu adanya pemberdayaan keluarga (orang tua/wali) tersebut sangat penting yang dikaukan baik oleh pemerintah, swasta maupun masyarakat secara umum. Seperti dilakukannya pemberdayaan ekonomi, pemberdayaan dari aspek mentalitas untuk benar-benar baik dalam proses mendidik anak. Ketika ekonomi keluarga tercukupi dan juga secara mental juga baik maka keluarganya pun akan mengetahui bahwa pengasuhan anak-anak merupakan tanggung jawab mereka.

Dari berbagai permasalahan yang ada maka perlu adanya pemanfaatan rumah singgah yang betul-betul dapat difungsikan dengan optimal sebagai wadah pemberdayaan dengan diadakannya petugas pelayanan yang dilengkapi dengan sarana dan prasarana lainnya dan dilakukan pendataan anakanak kemudian diuraikan permalahannya sehingga hal ini Dinas Sosial Kota Serang bekerjasama dengan OPD lainnya. selain itu, penting menyadarkan orang tua dimana walaupun memang orang tua mereka sebelumnya menjadi korban salah dalam pengasuhan atau faktor lain yang mengakibatkan mereka menjadi bagian dari anak jalanan seberlumnya, tetapi sekarang posisinya mereka sudah menjadi orang tua yang memiiliki tanggung jawab terhadap pengasuhan anak dalam arti orang tua tersebut harus disadarkan betul peran orang tua yang sebenarnya. Dalam hal ini, penanganan anak jalanan harus sampai ke hulu, dimana sebelumnya itu keluarga renta dan rawan yang menjadikan anak menjadi korban kekerasan sehingga menjadi keluarga yang memiliki ketahanan keluarga. Sehingga hak-hak anak terpenuhi dengan baik dan itu perlu adanya regulasi Pemerintah Kota Serang dengan cara membuat aturan bersama misalnya MoU dengan OPD lainnya yang terkait serta lembaga Ngo untuk mermbuat pedoman khsuusnya dalam penanganan anak jalanan. Jadi, penanganan anak jalanan tidak lagi hanya pada ranah Dinas Sosial Kota Serang. Tetapi bagaimanapun juga, keseriusan pemerintah terhadap permasalahan ini adalah dengan dibuatkannya regulasi khusus penanganan anak jalanan dimana di dalamnya harus di bahas bagaimana usaha preventif dan kuratif yang tertuang di dalam SOP. Tidak lagi mengacu pada regulasi penanganan anak jalanan dimana anak jalanan masuk ke dalam peraturan 
terkait PEKAT (Penyakit Masyarakat). oleh karena terbetuknya payung hukum yang khusus dan jelas yang akan berdampak pada mengalokasian anggaran yang diharapkan dapat berjalan dengan baik dalam menangani masalah ini.

Hasil yang di dapat pada indikator yang telah dipaparkan maka selain dibuatkannya regulasi secara khusus terkait penanganan anak jalanan yaitu dihidupkan kembali Program Rumah Singgah dengan manajemen rumah singgah yang baik yang telah dibuat oleh Dinas Sosial Kota Serang yang melibatkan OPD lain beserta LSM, swasta dan lembaga lain serta masyarakat pada umumnya yang memiliki keseriusan dan komitmen dimana dalam kegiatannya berbasis community devepoment.

\section{SIMPULAN}

Simpulan yang diperoleh dari hasil penelitian ini adalah ada terdapat hal-hal yang menyebabakan tidak sedikitnya anak jalanan di Kota Serang seperti faktor ekonomi, hukum, keluarga, budaya pendidikan dan lingkungan. Adapun upaya yang telah dilakukan oleh pemerintah tidak membuat anak jalanan berkurang karena minimnya keseriusan dan komitmen pemerintah dalam penangganan anak jalanan yang ada di Kota Serang. Upaya yang dimaksud yaitu berupa Program Post Sahabat Anak dan Program Rumah Singgah. Sampai pada saat ini kedua program berbasis community development tersebut tidak berjalan. Hal ini disebabkan juga karena regulasi yang masih belum spesifik mengenai penanggulangan anak jalanan. Artinya, regulasi mengenai anak jalanan ini masih dijadikan satu dengan penanggan masalah sosial lainnya yang disebut dengan penyakit masyarakat yaitu peraturan daerah Kota Serang Nomor 2 tahun 2010 Tentang Pencegahan, Pemberantasan dan Penanggulangan Penyakit Masyarakat. Adapun hasil penelitian ini dalam penanggulangan anak jalanan berbasis community development di Kota Serang yaitu menghidupkan kembali Program Rumah Singgah yang telah dibuat oleh Dinas Kota Serang sekitar tahun 2014/2015 khusus untuk anak jalanan dengan dibuatkannya manajemen program rumah singgah yang yang yang lebih matang sehingga fungsi rumah singgah ini diharapkan tidak hanya sekedar tempat untuk pendataan anak-anak yang sudah terkumpul tetapi harus ada tindak lanjut seperti lokasi terselenggaranya pendidikan dan keterampilan yang betulbetul fungsi masyarakat sebagai komunitas pembangunan khususnya 
dalam penanganan anak jalanan berjalan bersinergi dengan pemerintah. Selain itu, Dinas Kota Serang agar lebih serius bekerjasama dengan aparatur pemerintah lainnya, baik di Kota Serang maupun lintas kabupaten/kota bahkan provinsi, NGO, serta lembaga sosial lainnya yang benar-benar peduli dengan anak jalanan.

\section{DAFTAR PUSTAKA}

Fitri, A. N., Riana, A. W., \& Fedryansyah, M. (2015). 9 perlindungan hak-hak anak dalam upaya peningkatan kesejahteraan anak. PROSIDING KS: RISET \& $P K, 2$ (1), 45-50.

Ismail, A., Community, S., Officer, D., Plantation, W. K., Responsibility, C. S., Waru, K., ... Karim, A. (2017). Strategi Community Development Officer (CDO) PT Waru Kaltim Plantation (WKP) dalam Menyelesaikan masalah Corporate Social Responsibility (CSR) di Kecamatan Waru Desa Bangun Mulya (Periode Januari - Desember 2015 ), 5(1), 181-195.

Mansyur. Di Depan Mata Tetapi Terabaikan. Media Cetak Radar Banten (17/5/2018)

Moleong, L. J. (2007). Metode Penelitian Kualitatif. Bandung : Rosdakarya.

Nazir, M. (2005). Metode penelitian. Jakarta : Ghalia Indonesia.

Putri, F., Nulhaqim, S. A., Hidayat, E. N., Peksos, S., Jalanan, A., Seribu, K., ... Pusat, J. (2015). 14 peran pekerja sosial dalam penanganan anak jalanan. PROSIDING KS: RISET \& PKM, 2(1), 74-77.

Ronawaty Anasiru. (2011). Implementasi Model-model Kebijakan Penanggulangan Anak Jalanan di Kota Makassar. Sosiokonsepsia, 16(02), 175-186.

Soetomo. (2008). Strategi-strategi Pembangunan masyarakat. Yogyakarta : Pustaka Belajar.

Susilowati, D. (2017). Kebijakan penanggulangan anak jalanan di kota malang. SENASPRO (Seminar Nasional Dan Gelar Produk), 884889.

Suzzana. (2018). Pengalaman Perubahan Konsep Diri pada Anak Jalanan di panti Sosial Rehabilitasi Gelandangan, Pengemis, dan Terlantar di Sumatera Selatan Tahun 2016. Jurnal Keperawatan Sriwijaya, 5(1), 40-57.

Triyono, A. (2014). (Pos Pemberdayaan Keluarga) PT. Holcim Indonesia Tbk Pabrik Cilacap ABSTRAK:, VI, No. 2, 111-121.

Widayanti, S. (2012). Pemberdayaan Masyarakat: Pendekatan Teoritis. Ilmu Kesejahteraan Sosial, 1(1), 87102.

Dinas Sosial kota Serang, 2015-2016

Keputusan Mentri Sosial RI Nomor 15 A/HUK/2010 Tentang Panduan Umum Program Kesejahteraan Sosial Anak 